\title{
The late Captain George Maling, V.C., R.A.M.C.
}

On 24th January, 1967 in the V.C. Room of the R.A.M.C. Headquarter Mess a framed photograph of Captain George Maling was accepted by the Director General Army Medical Services from Brigadier W. Buffey, D.S.O., T.D., D.L. the Senior Trustee of the 4th London Trust. Captain Maling had served with the 4th City of London Brigade, Royal Artillery and had been a personal friend of the Brigadier.

Sir Robert Drew in accepting the gift on behalf of the Corps recounted the citation ${ }^{1}$ for the award of the Victoria Cross and expressed appreciation of this addition to a record of outstanding gallantry and devotion to duty on the part of an officer of the Corps. The Cross and other medals were to be seen in the V.C. Room. He was glad also. to welcome Captain Maling's widow Mrs. D. M. Maling, R.R.C. to the occasion. Amongst those present were the Representative Colonel Commandant (Major General T. F. M. Woods), Lieutenant-General Sir Alexander Drummond, Major General J. P. Douglas, The Commandant R.A.M. College (Major General Stephens) and a number of senior, junior and retired officers.

(1) Lieutenant Maling's citation for the award of the Victoria Cross.

"For conspicious bravery and devotion to duty during the heavy fighting near Fauguissart (Battle of Loos) on 25th September, 1915. Lieutenant Maling worked incessantly with untiring energy from 6-25 p.m. on the 25 th till 8 p.m. on 26 th, collecting and treating, in the open, under heavy shell fire, more than 300 men. At about 11 a.m. on the 25 th he was flung down and temporarily stunned by the bursting of a high explosive shell, which wounded his only assistant and killed several of his patients. A second shell soon after covered him and his instruments with debris, but his high courage and zeal never failed him, and he continued his gallant work single handed."

Lieutenant Maling at the time was M.O. to the 12th Bn. the Rifle Brigade.

\section{Harden Barracks}

The new barracks in Catterick for personnel serving at Catterick Military Hospital was named with effect from 1st December 1966-Harden Barracks. A plaque commemorating the naming of the barracks after Lance-Corporal Eric Harden, V.C., R.A.M.C. is to be affixed. 